\title{
Open education and the emancipation of academic labour'
}

Joss Winn, School of Education, University of Lincoln, Campus Way, Lincoln, LN6 7TS, UK.

\section{Abstract}

I have previously argued that open education is a liberal project with a focus on the freedom of things rather than the freedom of people. (Winn 2012) Furthermore, I have argued that despite an implicit critique of private property with its emphasis on 'the commons', the literature on open education offers no corresponding critique of academic labour (Neary and Winn 2012).

In this paper, I develop my critical position that an emancipatory form of education must work towards the emancipation of teachers and students from labour, the dynamic, social, creative source of value in capitalism. In making this argument, I first establish the fundamental characteristics of academic labour. I then offer a 'form-analytic' critique of open access, followed by a corresponding critique of its legal form. Finally, I critically discuss the potential of 'open co-operatives' as a transitional organisational form for the production of knowledge through which social relations become "transparent in their simplicity.” (Marx, 1976, 172)

\footnotetext{
${ }^{1}$ This is an Author's Original Manuscript of an article published by Taylor \& Francis in Learning, Media and Technology on 16th March 2015 available online at http://dx.doi.org/10.1080/17439884.2015.1015546
} 


\section{Keywords}

open education, open access, Marxism, value-form, co-operatives

\section{Introduction}

Over the past decade, an increasing number of academics, learning developers and university support staff have been campaigning for, developing and constituting the practice of 'openness' in higher education: open source software (OSS), OpenCourseWare (OCW), open educational resources (OER), open education (OE), open access (OA), massive open online courses (MOOCs), and open data are increasingly part of the fabric of higher education. (Kelly, Wilson, and Metcalfe 2007; Wiley 2006; Gil-Jaurena 2013)

Despite Peter and Deimann's (2013) effort to situate openness in higher education within a history of education that stretches back to the middle ages, the current form of openness in higher education is little more than a decade old. This current form can be distinguished as primarily legalistic, grounded in the development of a subversive form of intellectual property licensing that was pioneered by university computer programmers in the 1980s (Stallman 2010) and developed for wider cultural use by law professor, Lawrence Lessig and others, as the Creative Commons (CC) or Free Culture movement (Lessig 2004). The growing accessibility of the Internet beyond the confines of the industrial-military-academic complex (Winn 2013) has been combined with this legal 
virtuosity to form a praxis of openness among educators, students and in fact anyone with the requisite level of 'digital literacy'.

My approach to analysing open education draws from Karl Marx's critique of capitalism, which identifies the imposition of private property and wage-labour as the organising principle of the existing mode of production. This imposition has given rise to a “determinate logic" (Postone 1993, 285) that continually seeks to alienate labour from its full creative capacity (Wendling 2011) and reduce the necessity of labour-time in the production of value. For capital, the crucial role of all forms of education is to ensure the reproduction and improvement of labour in a historical form that is conducive to the production of value. For the student, education becomes necessary in order to improve the value of the labour power commodity upon which their subsistence depends. That is, the potential of education for personal enrichment is secondary to its value-forming purpose in capitalist society. (Rikowski 2011)

I begin this paper by discussing what I mean by 'academic labour' (elaborated further in Winn, 2014). This is because we can only critically understand open education if we have an adequate theory of the human labour which produces it. Next, I focus my discussion by providing an analysis of a key aspect of open education and one of its most mature components: Open access. In the next section, I develop my theoretical approach to understanding open education and focus specifically on the form and content of open licenses, such as Creative Commons. In the final section of this article I situate open education within a wider effort to overcome the contradiction of the commodification of knowledge, whereby immaterial abundance remains constrained by the imposition of material poverty. In doing so, I suggest it might be achieved through open, co-operative organisational and institutional forms that progress towards an emancipatory form of 
education through which human social life becomes the project rather than the resource. (Bonefeld 2014)

\section{What is academic labour?}

In Marx's critique of political economy, a thing that is produced for consumption by someone other than the producer herself is a 'commodity'. This does not include things that we produce for our dependents, such as making a meal for family and friends. In the critique of capitalism, we are concerned with general commodity exchange at the level of society and not reciprocity in the form of gifts, etc. The form of a commodity in its most abstract sense is two-fold: a commodity has a 'use-value' and 'exchange-value'. Use-value is the form of the commodity's "tangible, sensible form of existence", the "natural form" of the commodity. (Marx 1978, 134) Use-values can be goods or services, both material and immaterial. Exchange-value is how value is socially expressed or appears and has a particular social form: the 'value-form'. Marx discovered that the two-fold character of the commodity-form is actually an expression of the two-fold character of human labour in capitalist societies, so before discussing the product of labour, we must first be clear about the specific, historical form that labour takes.

As a critical category, 'labour' does not refer to the specific content of the undertaking (e.g. teaching), but rather to its form. As with commodities, Marx determined that labour in capitalist societies also has a dual character: 'concrete labour' and 'abstract labour'. Concrete labour is the physiological and useful work that individuals perform. Through the expenditure of concrete labour, we produce use-values. However, in order to quantify the value of individual concrete labour, it must be treated abstractly as the equivalent of other forms of individual labour. Abstract labour is the reduction of individual concrete labour to a qualitatively commensurable social form of labour. It is a 
reduction into "a definite quantity of equal, general, undifferentiated, social, abstract labour"; it is "labour pure and simple, abstract labour; absolutely indifferent to its particular specificity". (Marx 1993, 296) This equivalence is confirmed when the product of that individual labour is exchanged, usually for money. "Abstract labour is a relation of social validation that is constituted in exchange." (Heinrich 2012, 50)

Abstract labour is therefore a qualitative reduction of different types of concrete labour and a reduction of corresponding use-values to social use-values - "use-values for others". (Marx 1976,131) Once labour has been reduced in this way, it can then be quantitatively reduced to the labour time that is socially necessary to perform the labour. 'Socially necessary labour time" is "the labour time required to produce any use-value under the conditions of production normal for a given society and with the average degree of skill and intensity of labour prevalent in that society." (Marx 1976, 129) All labour throughout history occurs in time, but the value of capitalist labour is measured socially by time.

When labour is sold for a wage, it too becomes a commodity with a use-value and an exchange-value. Marx called this 'labour power': “the aggregate of those mental and physical capabilities existing in the physical form, the living personality, of a human being, capabilities which he sets in motion whenever he produces a use-value of any kind." (Marx 1976, 270; Rikowski 2002) As such, an academic exchanges their capacity to produce use-values for a wage, and the way in which that labour power is applied as 'labour' is defined by the employment contract.

As I have tried to emphasise with the brief account above, the importance of understanding Marx's analysis of labour in capitalism cannot be understated. It is, he said, "the pivot on which a clear comprehension of political economy turns" (Marx 1996, 51). He regarded "the two-fold character of labour according to whether it is expressed in use-value or exchange-value" as one of his most important discoveries and 
"fundamental to all understanding of the FACTS". (Marx 1987, 402) All forms of wage labour and its product can be analysed in this way, including labour in higher education.

\section{Open access and the commodity-form}

Having established the two-fold character of labour in capitalist society and its role as the commodity of labour power, we are now in a position to examine the nature of its products e.g. open access journal articles, books, etc.

Open access is defined as having two fundamental attributes: 1) Freedom: It must be free of cost for the reader to access and free of legal restrictions so as to permit re-use of the work; and 2) Persistence: It must be deposited in an appropriate online archive which safeguards the longevity of the freedoms defined by the first attribute. (Suber 2012) Since the second attribute is in support of the first, I will focus my discussion on the first attribute which is concerned with an exchange relationship of production and consumption. The open access movement is insistent that the reader should have access to the journal article free of cost (gratis) through an institutional archive. ${ }^{2}$ This is one of two types of freedom that open access is based upon, the second being 'libre' (free from some restrictions on re-use). (Suber 2012) I examine the first freedom (gratis) in this section of my paper and the second (libre) in the next section.

Marx referred to the 'commodity' as the "elementary form" of wealth. "Our investigation begins accordingly with the analysis of the commodity." (Marx 1976, 125) That is, we have to unravel how the commodity appears in order to understand the totality of capitalist social relations through which it was produced. If a product or service deriving

\footnotetext{
2 I am aware of the difference between 'green' and 'gold' and even 'diamond' OA. Here, I am trying to offer an abstract analysis of the ideal of $\mathrm{OA}$ as set out in the open access definition.
} 
from physical and mental labour has utility and is consumed by someone other than its producer, it has the form of a commodity. That is not to say that the owner of the commodity will profit from it or even that it has a price, but that it simply takes the form of a commodity. If an open access article is a commodity it must, according to Marx's analysis, simply have a use-value and an exchange-value.

In his analysis of exchange-value, Marx determined that the 'value-form' characterizes the exchange of use-values. He analysed the value-form starting from its most abstract and simple expression, 'ascending' to its expanded form, its general form, and finally its concrete money-form. "The secret of the entire value-form must be hidden in this simple value-form.” (Marx 1978, 134) In the simple form, two commodities simultaneously play two different roles. Commodity A is the commodity "which expresses its value in the body of a commodity different from it", commodity B. These "two poles of the expression of value" (135) are relative and equivalent positions. Each commodity "serves as the material in which value is expressed. The one commodity plays an active and the other a passive role." (134) An example would be: a litre of milk is worth half a dozen eggs.

If we stopped here in our analysis, we might conclude that the open access journal article is not a commodity because it is not being directly exchanged (i.e. bartered) for another commodity, as in the simple value-form. However, Marx's elucidation of the simple value-form is pedagogic. Although historically such simple exchange did take place, the presentation of Marx's analysis is not historical-logical but dialectical. (Bellofiore and Redolfi Riva, 2015) The simple value-form is key to understanding the capitalist form of value because it follows that if a single commodity can be relative in value to another single commodity, then it can also be relative to other commodities. Marx called this next stage in his presentation the 'expanded value-form'. Therefore, commodity A is not just 
exchangeable with commodity B, but also with commodity C, D, E, and so on. An example would be: a litre of milk is worth half a dozen eggs or $100 \mathrm{~g}$ of tea or one bus ride, etc.

Marx identified three "deficiencies" of the 'expanded value-form'. In such exchange relations, there is no 'conclusion' in a final expression of value, such as money. As such, the value of a commodity is only ever expressed in a limited number of equivalent commodities while excluding others. Furthermore, the human labour contained by the commodity is only ever expressed in a particular commodity, rather than a general unified form. Thus, just as we moved from an analysis of the simple form to the expanded form, we must also move from the expanded form to the 'general value-form'. In this overall analytical transition from the simple to the expanded to the general and eventually the money-form, we move to an overall more social form of commodity exchange, which can only operate through increasing levels of abstraction in daily life. With the general value-form a commodity becomes relative to any other commodity. It becomes "simple and common, i.e. general." An example would be: a litre of milk is worth half a dozen eggs, $100 \mathrm{~g}$ of tea, one bus ride, etc. In our case, the open access journal article "now counts for the bodies of all the different sorts of commodities as their common and general shape of value." (Marx 1978, 146) The expression of value in the open access journal article,

"now distinguishes the commodity not only as value from its own existence as a useful object, i.e. from its own natural form, but at the same time relates it as value to all other commodities, to all commodities as equal to it. Hence in this value-form it possesses general social form." Marx 1978, 146) 
What is crucial about the transition to the general value-form is that it is from here that we understand how labour is the source of social wealth i.e. 'value'. Here, a commodity becomes an expression of the general, undifferentiated form of labour: abstract labour.

Throughout his analysis, Marx used linen and coats as his examples of commodities and weaving and tailoring as the respective types of labour.

"Only through this general character does the value-form correspond to the concept of value. The value-form had to be a form in which commodities appear for one another as a mere jelly of undifferentiated, homogenous human labour, i.e. as expressions in the form of things of the same labour-substance. This is now attained. For they are all material expressions of the same labour, of the labour contained in the linen or as the same material expression of labour, namely as linen. Thus they are qualitatively equated." (Marx 1978, 146-7)

At this point in his elucidation of the value-form of commodities, Marx has determined that just as all commodities are relative to one another, each can also take on a general, social form of equivalence. The "natural form" of a commodity (e.g. the specific character of the open access journal article) "is therefore at the same time its general social form." (Marx 1978, 147) That is, all use-values that can be exchanged also possess a general social form whereby they can be understood as equivalent to any other usevalue.

"For all other commodities, although they are products of the most different sorts of labour, the linen counts as the form of appearance of the labours contained in them, hence as the embodiment of homogenous undifferentiated human labour. Weaving - this particular concrete type of labour - counts now by virtue of the value-relation of the world of commodities to linen as the general and immediately exhaustive form of realisation of abstract buman labour, i.e. of the expenditure of buman labour-power as such. 
For precisely this reason the private labour contained in linen also counts as labour which is immediately in general social form or in the form of equality with all other labours. If a commodity thus possesses the general equivalent-form or functions as general equivalent, its natural or bodily form counts as the visible incarnation, the general social chrysalis of all buman labour." (Marx 1978, 147)

If we simply replace 'linen' with 'open access journal article' and 'weaving' with 'researching', does Marx's analysis still hold? Yes, of course because there is a common qualitative substance shared by both the linen and the open access article, one common to both the labour of an academic and the labour of a weaver: human abstract labour. Thus, the labour of the academic who writes the open access article cannot be conceived in isolation from all other products of labour being exchanged in the social world of capitalism. Under capitalism, individual labour is at the same time social labour.

In Marx's analysis of the value-form, the 'general form' of value, explains how commodities share the same qualitative substance of abstract labour but in the process of exchange one commodity's relationship with another remains exclusive to another specific commodity i.e. the open access article is exchangeable with any other commodity, but still within the logic of bartering one thing for another. As Marx noted, "[t]he general equivalent-form is a form of value as such. It can therefore pertain to any commodity, but always only by exclusion from all other commodities.” (Marx 1978, 148)

Historically, Marx argued, a necessary universally equivalent form of value was developed; one that overcomes the exclusive limitation of the general value-form. That universal equivalent is the commodity of money.

"Now the specific type of commodity with whose natural form the equivalent form coalesces socially becomes the money-commodity or functions as money. Its specific social function and 
hence its social monopoly becomes the playing of the role of general equivalent within the world of commodities." (Marx 1978, 149)

We have seen that from this explication of the commodity-form, it must have a use-value and an exchange-value, and at this formal level of analysis the specific price of the commodity is irrelevant. As we know, the price of something does not indicate whether the exchange will realise a profit ('surplus value'). In some cases commodities might be sold below their production costs so as to get rid of them urgently, or as 'loss leaders' to entice related purchases. We must not confuse the idea of something having a price or making a profit, with the distinction of whether it takes on the form of a commodity.

Of course, most commodities are priced so that their direct exchange for money does produce a surplus of value over and above the total cost of production, which begs the questions, 'how and why can open access journal articles be made available for free?' This is the perennial question that concerns some academics and their institutions but mainly the publishing industry and policy makers (Finch 2012; Vincent 2013). Various business models and measures of 'impact' are currently being discussed and implemented (Bastow 2014; HEFCE 2014), which are intended to demonstrate the value of academic research, and it is here where the role of abstract labour as the substance of value becomes most clearly articulated. The journal article

"is value only to the extent that it is the expression, in the form of a thing, of the human labour-power expended in its production and thus insofar as it is a jelly of abstract human labour - abstract labour, because abstraction is made from the definite useful concrete character of the labour contained in it, human labour, because the labour counts here only as expenditure of human labour-power as such." (Marx 1978, 1367) 
As a universal equivalent, money does not need to be exchanged directly for the individual product in which the value of labour appears to be invested. As we have seen, the simple form of value sufficiently articulates that in any such exchange it is always abstract labour acting as the relative value-form and money as the equivalent form. As an individual's labour power assumes an abstract form it becomes "congealed" (Marx 1976, 128) into the social body of labour within the institution employing it and can meet its equivalent in money through a variety of possible exchanges. Thus, the journal article accessed freely from a university research repository is not directly exchanged for money, but money is still anticipated by the institution in exchange for this provision. The university has advanced some money in the form of a wage (Heinrich 2012,120) to the academic who has produced the open access article, which is made available at zero price and the expectation is that a return will be made in the form of money (grants, tuition fees, consultancy, patents, etc.) in exchange for that initial advance.

In short, wherever there is wage labour, there is concrete and abstract labour and therefore the corresponding characteristics of its product: the commodity with a usevalue and an exchange-value. The universality of the money-form means that one does not have to engage in the 'simple' and direct exchange of one commodity for another, for as long as the value of social, abstract labour is exchanged with its equivalent value in the form of money (i.e. the monthly wage is advanced not spent), then some products of labour which take the form of commodities can appear to be 'given away'. What this analysis points to is that the current debates around open access represent a struggle with capital over the form and purpose of academic labour. It is a struggle not simply over the freedom to access and re-use knowledge but rather one that implicitly questions the conversion of academic labour into money.

\section{Licenses and the law of labour}


"Right can never be bigher than the economic structure of society and its cultural development which this determines." (Marx 1989, 87)

"Law is not a set of coercive rules, but a tangible expression of a social form with a predetermined historical content, namely the commodity nature of the products of labour under a regime of absolute property." (Kay and Mott 1982, 94)

So far, I have established that an open access journal article, which is free (gratis) at the point of exchange, takes the form of a commodity that expresses the form of labour. Next, I want to argue that the legal form of 'open (libre) licenses' such as Creative Commons is itself derived from the commodity-form and within the existing economic structure of society and its cultural development, represents a subversive, transitional expression of right under a regime of absolute property.

We have seen that, according to Marx's critique of political economy, the commodity is the "economic cell-form" (Marx 1976, 90) of the capitalist mode of production. As such, the commodity-form is the premise for other social forms and thus,

\section{"In as much as the wealth of capitalist society appears as "an immense collection of commodities", so this society itself appears as an endless chain of legal relations." (Pashukanis} $1989,85)$

This is the argument made in the early twentieth century by the Russian legal scholar Pashukanis (1989) and more recently by Mieville (2005) in his study of international law. By examining open licenses through Pashukanis' 'general theory' of law, we are able to show how key features of such licenses both express and subvert the commodity-form and can be understood to represent the movement towards a new form of social wealth. 
The use of open licenses such as Creative Commons is an essential component and characteristic of the open education movement. As well as being fundamental to the definition of open access journal articles, books, etc, such licenses are part of what also defines open educational resources. (Cape Town Open Education Declaration 2007) The specific choice of license conforms to existing socially accepted norms. For OERs, the most common type of license is a 'copyleft' license that requires creators of derivative works to apply the same type of license as the originating work (Stallman 2002, 89-93). For example, the P2PU uses a CC BY-SA (Creative Commons, Attribution, Share-Alike) license $^{3}$ and MIT's OpenCourseWare uses a CC BY-NC-SA (non-commercial) license. ${ }^{4}$ Over $80 \%$ of individuals who have deposited OERs in the UK's JORUM repository have chosen a copyleft/share-alike license, and of those over $90 \%$ carry the noncommercial clause. ${ }^{5}$ Thus, we can say that the current social custom is to apply a noncommercial copyleft license to open educational resources.

For open access articles the social custom is quite different, although gradually changing. Research Councils and major publishers agree on the use of a non-copyleft, or 'permissive' CC BY license, free of most restrictions but requiring attribution for the creator of the work (RCUK 2013). However, the actual adoption of this license to-date remains relatively small and the preference among authors and many smaller journals is for no license, i.e. protected by copyright but accessible without charge (gratis rather than libre) or for CC BY-NC-ND, thus not conforming to the basic definition of open access (Herb 2014; Taylor \& Francis 2014).

\footnotetext{
${ }^{3}$ https://p2pu.org/en/pages/license/

${ }^{4}$ http://ocw.mit.edu/terms/

5 This was the case on $30^{\text {th }}$ June 2014, having undertaken a search, filtered by license. http:// find.jorum.ac.uk/
} 
In his introduction to Pashukani's major work, The General Theory of Law and Marxism, Arthur argues that Pashukanis provides a materialist approach to a theory of law which can be distinguished from "a radicalism that unconsciously remains imprisoned within a bourgeois frame of reference." (Pashukanis 1989, 9) Such 'radicalism' today is epitomized by much of the free culture movement; what Coleman has identified in open source culture as a "liberal critique from within liberalism." (Coleman 2012, 3). In contrast, a materialist approach is not only concerned with the content of the legal regulation, but also its form, recognizing that law is the "necessary expression of the economic content at a specific level of the social structure." (Pashukanis 1989, 11) As such, this approach to analyzing 'the law' i.e. legal regulation, through the 'law form', conforms to Marx's critical method whereby concrete features of social life can only be fully understood as the concentration of historical, determinate abstractions.

"The concrete is concrete because it is the concentration of many determinations, bence unity of the diverse. It appears in the process of thinking, therefore, as a process of concentration, as a result, not as a point of departure, even though it is the point of departure in reality and hence also the point of departure for observation and conception. ... the abstract determinations lead towards a reproduction of the concrete by way of thought." (Marx 1993, 101)

In his book, Pashukanis devotes the first chapter to discussing this method of "rising from the abstract to the concrete". On the basis of this scientific method, he argues, "Hence law in its general definitions, law as a form, does not exist in the heads and theories of learned jurists. It has a parallel, real bistory which unfolds not as a set of ideas, but as a specific set of relations which men enter into not by conscious choice, but because the relations of production compel them to do so. Man becomes a legal subject by virtue of the same necessity which transforms the product of nature into a commodity complete with the enigmatic property of value." (Pashukanis 1989, 68) 
Through a dialectical analysis of the legal form and its content, Pashukanis demonstrates that just as Marx had shown how bourgeois categories of economics reflect the development of bourgeois society and are inadequate for reflexive critical inquiry, legal categories also reflect aspects of the bourgeois historical subject which is based on the production of commodities i.e. the commodity-form. Thus,

\author{
"we must start with an analysis of the legal form in its most abstract and pure shape and then \\ work towards the historically concrete by making things more complex... Only then shall we \\ comprehend law not as an appendage of human society in the abstract, but as an historical \\ category corresponding to a particular social environment based on the conflict of private \\ interests." (Pashukanis 1989, 71-2)
}

Having established my basic methodological and theoretical approach to analysing the role and character of open licenses in the open education movement, I now want to offer a more detailed analysis of the legal form of open education and argue that certain characteristics of the content of its adopted licenses indicate an immanent movement towards the dissolution of liberal subjectivity, despite remaining within the confines of the law form.

Copyright, which is the legal basis for open licenses, exists to affirm and protect the private interests of a legal subject who has invested labour time in their product. As equal legal subjects, both parties in an exchange relation are set in opposition to each other and the law protects them from the possibility of dispute. In a hierarchical society based on relations of command, the potential for such dispute between two equal subjects is absent but in a capitalist society based fundamentally on the idea and practice of equivalence, the possibility of dispute between two rights holders is always implied. (Mieville 2005, 79) In this context, we see why a license is a form of contract through which "the property holder effectively promises not to sue someone else for actions that 
would ordinarily infringe the property holder's exclusive rights”. (Lindberg 2008, 135) It explicitly extends the rights over the use of an individual's property in a way that seeks to avoid contestation.

Creative Commons licenses rest on the authority of copyright, a property law based on the principles of expression and defaults. 'Expression' refers to "personal expression in all its varieties" (Lindberg 2008, 72) and 'defaults' refers to the application of copyright law to a creative expression without the need to register ownership, but rather it is protected by default from the moment it is " ffixed in a tangible medium of expression."” (76) This law permits the copyright holder to permissively extend the legal regulation of their property in a way that anticipates and promotes a clearly defined type of exchange. "At its core, open source is a legal construct for the cooperation and trade in intellectual property." (155) Similarly, open education is based on a legal construct for the cooperation and trade in intellectual property.

In developing a framework for understanding open source, Lindberg uses the analogy of credit unions, arguing that like credit unions, open source projects can be understood as "cooperative model organisations" (Lindberg 2008, 155) as distinct from corporate model organisations. "The first and most fundamental feature distinguishing corporate and cooperative organisations is ownership." (156) In the cooperative organization, the interests of its members are aligned around shared control and effective ownership of the property i.e. copyright. 'Membership' is based on the fact that each has "refused to exercise the prerogatives of exclusive personal ownership.” (157) Where no money exchanges for openly licensed goods, a "barter of value between contributors" still remains. Like open source, open education is free "only if your time has no value". (159, quoting Zawinsky) 
This latter point is key to understanding and developing a critique of open licenses as they pertain to the production of commodities. Although the work is usually free (gratis), in the case of OA journal articles and OERs, the work still embodies the wage labour of the individual creator(s), measured by the labour time socially necessary to produce the commodity. The advance of the wage by the academic's employer naturally anticipates a return of some kind in the form of money; such is the basis of the contract between employer and employee: the exploitation of labour power so as to produce surplus value.

Reflecting labour legislation, the employment contract is a form of mutual recognition of rights between employer and employee over the exchange of the labour power commodity for money, just as the license is a form of mutual recognition of rights between abstract and equal subjects over the exchange of a use-value such as a journal article. The commodity of labour power and the commodity of the journal article are both forms of property as defined by their respective employment and copyright contracts. It is at the point of exchange, of converting labour power into labour, usevalue into exchange-value, that the abstraction of 'right' comes into force and is first defined by default in copyright law and simultaneous extended through the rights asserted by the license contract. The specific legal claims of each license will differ but the abstract form of right necessarily accompanies the abstraction of labour as it moves from the production of use-values to their distribution and circulation.

By default, it is the copyright license (e.g. Creative Commons) that validates the open access article as a use-value (property) for exchange (a commodity). The license not only permits an actual exchange between subjects with equal rights but its existence always implies an exchange of property between equal legal subjects. In this way the legal content of the license itself is an expression of the abstract legal form that is derived from the value-form of equivalence. The dialectic at work with the use and promotion of open 
licenses is that their content promotes the co-operative production and exchange of usevalues over and above their realisation of surplus value, yet they do so according to a legal form which has as its end objective the circulation of commodities (Pashukanis 1989, 100).

The origins of open education as it is understood today are in the free and open source software movement. Weber argues that for open source communities, "licenses act as the practical manifestation of a social structure that underlies the open source process." The use of these licenses acts as "an ordering device" in the absence of an organization so that "licensing schemes are, in fact, the major formal social structure surrounding open source." (Weber 2004, 85) Pashukanis' analysis goes deeper to show how the "major formal social structure" is in fact the commodity-form, from which the law form and its expression in contract law are derived. This distinction between legal form, the law and its role in structuring social relations is resolved by Mieville, who argues that administration within civic and corporate life is a concrete expressions of the abstract legal form.

"Administration is law: it is somewhat removed from private law, where the legal form exists in its 'purest' form, but administration - public law - is directly derived from that form. Only in the context of generalized commodification and juridical relations does administration manifest through the specific form of 'administrative law'." (Mieville 2005, 110)

In the absence of an organisational form, open licenses mediate social relations. Along with a technical apparatus that is defined by protocol, licenses also fulfill a need for administration in the context of decentralization. (Galloway 2004)

Like open source, open education is an expression of co-operative labour which is dialectically subjected to the legal form of commodity production yet undermines the 'natural' authority of that form through the subversive content of its licenses which act as a 
form of administration in the absence of specific organisational structures. This particular combination of openness and co-operativism has recently led to the proposal of 'open co-operatives', which seek to ground the principles and objectives of openness in the values and principles of the co-operative movement, thus attempting to resolve the contradiction of immaterial abundance and material poverty. In the next section, I will introduce work that is emerging in this area.

\section{Open Educational Co-operatives}

A dialectical tension exists within open education between the distributed, 'networked' possibility of abundance and the private, corporate institutional form of the universities that sustain it. Although the values of openness, sharing and consensus are clearly shared by many academics and students, the administration of universities is increasingly being subjected to undemocratic executive control, marketisation and financial speculation. (McGettigan 2013) This tension has been conceived by Kelty more generally in terms of a 'recursive public', "a public that is constituted by a shared concern for maintaining the means of association through which they come together as a public" (Kelty 2008, 28). In the case of open education, it raises the question of which organisational form is adequate as a means of association that constitutes the shared concerns of its practitioners.

Recently, 'open co-operatives' have been advocated as a new, progressive organisational form to address the "paradox" of immaterial abundance existing alongside material scarcity. (Bauwens 2014; Bauwens and Kostakis 2014) What fundamentally distinguishes these from other forms of co-operative is the promotion of a new type of open license, referred to as 'Commons-Based Reciprocity Licenses'. 
"The key rules of such licenses are: 1) the commons are open to non-commercial usage 2) the commons are open to common good institutions 3) the commons are open to for-profit enterprises who contribute to the commons. The exception introduced here is that for-profit companies that do not contribute to the commons have to pay for the use of the license. This is not primarily to generate income, but to introduce the notion of reciprocity in the market economy. In other words, the aim is to create an ethical economy, a non-capitalist market dynamic." (Baunens 2014)

An example of such a license is the Peer Production License (PPL), a so-called 'copyfarleft' license created by Dmytri Kleiner. ${ }^{6}$ The PPL is based on the Creative Commons BY-NC-SA v3.0 license with an additional restriction. (Peer Production License) Like the CC license, the PPL requires the consumer of the commodity to 'share alike' by licensing any derivative commodity under the same terms. This strategically develops a commons of social property. This social property is not 'public' in terms of regulated by the state, nor individually or collectively 'private' as in joint-stock. The PPL also asserts that no commercial use shall be made of the commodity meaning that it cannot be used for commercial advantage or private monetary gain i.e. profit. This attempts to resist the exploitation of the co-operative's labour for the creation of surplus value. The license also asserts that attribution be given to the originating producer of the commodity. This resists the dissolution of the property into the public domain and ensures that the originating producer(s) are credited for their contribution. It also adds a dimension of transparency as to the provenance of each contribution. This is important for a system that is based on any kind of reciprocity. The unique addition to these restrictions in the PPL is an exception to the non-commercial clause stating that

\footnotetext{
${ }^{6}$ For material goods, the practice of 'Venture Communism' is advocated (http://p2pfoundation.net/Venture_Communism). I do not have space to discuss this aspect of open cooperatives here and in the context of open education must give priority to immaterial commodity exchange.
} 
commercial use can be made of the product by democratic, worker-owned organisations that distribute their profits (surplus) among themselves e.g. worker co-operatives. This is to allow the re-use of the social property of co-operatives in their mutual interest of building a commons. It applies to the immaterial, non-rivalrous knowledge products of the co-operatives and permits a restricted type of quasi-commercial practice among cooperatives while resisting the dissolution of the commons into the anti-social private sphere.

A key part of the debate ${ }^{7}$ around open co-operatives and the PPL focuses on the form that reciprocity would take. For Bauwens and Kostakis, commons-based reciprocity licenses like the PPL would "limit the non-reciprocity for for-profit entities, however they would not demand equivalent exchange, but only some form of negotiated reciprocity." (Bauwens and Kostakis 2014, 359) Such reciprocity is deemed "direct", unlike non-reciprocal licenses such as the GPL, which they describe as "communistic" in contrast to their "socialist" form of license.

Although they do not draw directly on the text, their argument aligns with that of Marx in the Critique of the Gotha Programme (Marx 1989). In that late text, he anticipates a staged transition from capitalism to communism, recognising that the bourgeois principle of 'equal right' would persist until it evidently became anachronistic to the economic structure of society.

"What we are dealing with here is a communist society, not as it has developed on its own foundations, but on the contrary, just as it emerges from capitalist society, which is thus in every

\footnotetext{
${ }^{7}$ See Vieira and De Filippi (2014); Bauwens and Kostakis (2014); Meretz (2014); Rigi (2014)
} 
respect, economically, morally and intellectually, still stamped with the birth-marks of the old society from whose womb it emerges." (Marx 1989, 85)

It is fundamental to Marx's historical materialist theory and method that the specific historical mode of production produces culture (Marx and Engels 1975, 31-32). In a transition from one mode of production to another, social relations will retain their earlier form despite growing evidence of their contradictory nature. Marx identifies the principle of "equal right" as a "bourgeois limitation" that will gradually become redundant through the development of economic forces; an inevitable defect in the "first phase of communist society". He explains that "Right, by its very nature, can consist only in the application of an equal standard" (Marx 1989, 86-7) recognising that individuals differ but under the capitalist mode of production individuals become equal legal subjects: abstract labour. Marx attacks the idea of the "fair distribution of the proceeds of labour", (84) arguing that what we might consider "fair" today, is only so from the standpoint of the capitalist mode of production and should not be assumed so for postcapitalist society. Such terms are "dogmas, ideas which in a certain period had some meaning but have now become obsolete verbal rubbish". (87)

Bauwens and Kostakis repeatedly emphasise that their advocacy of commons-based reciprocity is strategic, arguing that licenses such as the GPL do not recognise the actual, existing need for direct forms of reciprocity should we wish to establish an "autonomous sphere of peer production" apart from capital. Such reciprocity is only demanded from for-profit firms as a way to ensure that they contribute to the growth of the co-operative commons. In this way, commons-based reciprocity licenses are an attempt to halt the accumulation by capital of value produced by co-operatives, allowing for its nonreciprocal, 'share alike' redistribution within the co-operative sphere. This emphasis on 
distribution is a conscious intervention to transform production. They argue that such licenses

"are not merely about redistribution of value, but about changing the mode of production. Our approach is to transform really existing peer production, which is today not a full mode of production being incapable of assuring its own self-reproduction. This is exactly why the convergence of peer production in the sphere of abundance must be linked to the sphere of cooperative production, and thus insure [sic] its self-reproduction." (Bauwens and Kostakis 2014, 360)

Bauwens and Kostakis have been criticised for advocating measures to resist capital, while retaining many of its key categories (Rigi 2014, 393-4). Yet their approach should be seen as strategic and grounded in their own evaluation of our present economic structures and the overwhelming persistence of the bourgeois principle of equal right. As such, their proposals require serious consideration while recognising that they are not conclusive in terms of overcoming the capitalist mode of production. Key to that task is to overcome the naturalisation of the idea of reciprocity as equivalence through the abolition of its social substance: value.

What does it mean to abolish value? It means that the 'value-form' (the exchange of relative and equivalent use-values) no longer mediates our social relations as it does today; it means that the commodity-form no longer determines our social relations. Since the commodity-form is nothing more than the expression of the dual character of labour, we find that the abolition of value is in fact the abolition of labour, i.e. the abolition of the abstract, social, homogeneous form of labour brought about due to the division of labour and its corresponding institution of private property. With this uniquely capitalist, qualitative form of labour abolished, its measure of 'socially necessary labour time' would be redundant. In moving towards this form of social relations, labour, according to Marx, 
would transition gradually from being 'indirect' as it is now, mediated by a specific form of exchange, to being 'direct labour', characterised not by equivalence, but by the social custom of 'from each according to their abilities, to each according to their needs.' Such a social custom is not the product of the creation of a new form of exchange, but rather a new mode of production based on freely associated concrete labour. Freedom then, is freedom from abstract labour measured by socially necessary labour time (i.e. freedom from value). The challenge for both open co-operatives and open education is to work towards the creation of a new, sustainable form of social wealth that is built upon the general social knowledge developed through and beyond the capitalist mode of production. To this end, an increasing number of academics and activists are now working to develop co-operative forms of higher education, ${ }^{8}$ which like open cooperatives, might be based on the worker co-operative model and therefore a radically different configuration of academic labour, property and pedagogy than that which exists in mainstream higher education. (Winn 2015; Social Science Centre 2013)

\section{Conclusion}

"Let us therefore, in company with the owner of money and the owner of labour-power, leave this noisy sphere, where everything takes place on the surface and in full view of everyone, and follow them into the hidden abode of production". (Marx 1976, 279)

In this paper, I have attempted to analyse the "hidden abode" of open education through a critique of open access and its legal form. In doing so, I have often departed from a direct discussion of how open education appears in terms of its content and tried to develop an analytical critique of its main forms. In the final section, I have discussed

\footnotetext{
${ }^{8}$ I currently maintain a bibliography which records this work: http://josswinn.org/2013/11/co-operativeuniversities-a-bibliography/
} 
recent proposals to co-operatively and materially constitute abundance against the logic of property or absolute poverty.

The Historian, Moishe Postone (1993), argues that industrial production is intrinsic to capitalism and that post-capitalism will be characterised by a post-industrial form of production. The P2P production of knowledge and its material effects could be, as Bauwens and Kostakis argues, a "proto-mode of production" for a future society (Bauwens and Kostakis 2014, 358), and producer co-operatives of freely associated labour could be its organisational form. Furthermore, the successful creation of a postcapitalist society will require a thoroughly global perspective, rather than a retreat into localism and guild-like modes of production and it will build on the achievements of capitalism as a highly productive, though devastating, historical mode of production.

Based on the distributed production of general, social knowledge, open education offers a vivid example of Marx's notion of the 'general intellect', whereby the achievements of cumulative human knowledge (e.g. science and technology) indicate "to what degree general social knowledge has become a direct force of production, and to what degree, hence, the conditions of the process of social life itself have come under the control of the general intellect and been transformed in accordance with it." (Marx 1993, 706; Neary and Winn 2009). Yet the mobilisation of the general intellect increasingly renders the need for human labour superfluous, despite it being the very thing on which capitalist expansiveness is based. The task for the open education movement is to assess how the material conditions upon which it thrives are, under the logic of commodity production, antithetical to the role of labour that is the substance of its value. What is required is for some of the extraordinary human energy contained in that labour to be directed towards forms of immanent, critical inquiry that aim to establish new forms of free association 
and the requisite social and organisational forms to sustain them as prefigurative of a future beyond the law of labour.

\section{References}

Bastow, Simon, Patrick Dunleavy, and Jane Tinkler. 2014. The Impact of the Social Sciences. How Academics and their Research Make a Difference. London: Sage.

Bauwens, Michel. 2014. "Why We Need a New Kind of Open Cooperatives for the P2P Age.” P2P Foundation. Accessed $18^{\text {th }}$ July 2014. http://blog.p2pfoundation.net/why-weneed-a-new-kind-of-open-cooperativism-for-the-p2p-age/2014/06/16

Bauwens, Michel and Vasilis Kostakis. 2014. "From the Communism of Capital to Capital for the Commons: Towards an Open Co-operativism." triple $C$ : Communication, Capitalism and Critique 12 (1): 356-361.

Bellofiore, Riccardo and Tommaso Redolfi Riva. 2015. "The Neue Marx-Lektüre

Putting the critique of political economy back into the critique of society." Radical Philosophy, 189: 24-36.

Bonefeld, Werner. 2014. Critical Theory and the Critique of Political Economy: On Subversion and Negative Reason. London: Bloomsbury.

Cape Town Open Education Declaration. 2007. Accessed 18 ${ }^{\text {th }}$ July 2014. http://www.capetowndeclaration.org/read-the-declaration

Coleman, E. Gabriella. 2012. Coding Freedom. The Ethics and Aesthetics of Hacking. New Jersey: Princeton University Press. 
Finch, Janet. 2012. Accessibility, sustainability, excellence: how to expand access to research publications. Accessed on 18th July 2014.

http://www.researchinfonet.org/publish/finch/

Galloway, Alexander R. 2004. Protocol. How Control Exists after Decentralization. Cambridge: MIT Press.

Gil-Jaurena, Inés. 2013. “Openness in higher education.” Open Praxis 5 (1) 3-5.

Heinrich, Michael. 2012. An Introduction to the Three Volumes of Karl Marx's Capital. New York: Monthly Review Press.

Herb, Ulrich. 2014. "Total numbers and shares of Open Access Journals using Creative Commons Licenses as listed by the Directory of Open Access Journals.” Accessed on 18th July 2014. http://dx.doi.org/10.5281/zenodo.8327

HEFCE. 2014. Independent review of the role of metrics in research assessment. Accessed on 18th July 2014.

http://www.hefce.ac.uk/whatwedo/rsrch/howfundr/metrics/

Hudis, Peter. 2012. Marx's Concept of the Alternative to Capitalism. Leiden: Brill.

Kay, Geoffrey and James Mott. 1982. Political Order and the Law of Labour. London: The Macmillan Press.

Kelly, Brian, Scott Wilson, and Randy Metcalfe. 2007. “Openness in Higher Education: Open Source, Open Standards, Open Access.” In ELPUB2007, Openness in Digital Publishing: Awareness, Discovery and Access - Proceedings of the 11th International Conference on Electronic Publishing, edited by Leslie Chan and Bob Martens, 161-174. 
Kelty, Christopher M. 2008. Two Bits. The Cultural Significance of Free Software. London:

Duke University Press.

Lindberg, Van. 2008. Intellectual Property and Open Source. A Practical Guide to Protecting Code. Sebastopol: O’Reilly.

Lessig, Lawrence. 2004. Free Culture: How Big Media Uses Technology and the Law to Lock Down Culture and Control Creativity. London: Penguin.

Marx, Karl and Frederick Engels. 1975. The German Ideology, Marx and Engels Collected Works Vol. 5. London: Lawrence and Wishart Ltd.

Marx, Karl. 1976. Capital, Volume 1. London: Penguin Classics.

Marx, Karl. 1978. “The Value-Form.” Capital and Class, 4: 130-150.

Marx, Karl. 1987. 1864-68, Letters. Marx and Engels Collected Works Vol. 42. London: Lawrence and Wishart Ltd.

Marx, Karl. 1989. Critique of the Gotha Programme. Marx and Engels Collected Works Vol. 24. London: Lawrence and Wishart Ltd.

Marx, Karl. 1993. Grundrisse. London: Penguin Classics.

Marx, Karl. 1996. Capital Volume 1. Marx and Engels Collected Works, Vol. 35. London: Lawrence and Wishart Ltd.

McGettigan, Andrew. 2013. The Great University Gamble: Money, Markets and the Future of Higher Education. London: Pluto Press.

Meretz, Stefan. 2014. "Socialist Licenses? A Rejoinder to Michel Bauwens and Vasilis Kostakis." tripleC : Communication, Capitalism and Critique, 12 (1): 362-365. 
Mieville, China. 2005. Between Equal Rights. A Marxist Theory of International Law. Leiden: Boston.

Neary, Mike and Joss Winn. 2009. “The student as producer: reinventing the student experience in higher education." In The future of higher education: policy, pedagogy and the student experience, edited by Bell, Les, Howard Stevenson and Mike Neary. London: Continuum Neary, Mike and Joss Winn. 2012. "Open education: common(s), commonism and the new common wealth.” Ephemera: Theory \& Politics in Organization, 12 (4): 406-422.

Pashukanis, Evgeny B. 1989. Law and Marxism. A General Theory. London: Pluto Press.

Peer Production License. Accessed $18^{\text {th }}$ July 2014.

http://p2pfoundation.net/Peer_Production_License

Peter, Sandra and Markus Deimann. 2013. "On the role of openness in higher education: A historical reconstruction." Open Praxis 5 (1): 7-14.

Postone, Moishe. 1993. Time, Labour and Social Domination. Cambridge: Cambridge University Press.

Postone, Moishe. 2012. "Exigency of Time: A Conversation with Harry Harootunian and Moishe Postone." Concentric: Literary and Cultural Studies 38 (2): 7-43.

RCUK. 2013. RCUK Policy on Open Access. Accessed on $18^{\text {th }}$ July 2014. http://www.rcuk.ac.uk/research/openaccess/policy/

Rigi, Jakob. 2014. “The Coming Revolution of Peer Production and Revolutionary Cooperatives. A Response to Michel Bauwens, Vasilis Kostakis and Stefan Meretz.” tripleC : Communication, Capitalism and Critique, 12 (1): 390-404. 
Rikowski, Glenn. 2002. “Fuel for the Living Fire: Labour Power!” In The Labour Debate: An Investigation into the Theory and Reality of Capitalist Work, edited by Michael Neary and Ana Dinerstein, 179-202. Aldershot: Ashgate Publishing Company

Rikowski, Glenn. 2011. "Capitorg: Education and the Constitution of the Human in Contemporary Society." Paper presented at the Praxis \& Pedagogy Research Seminar, The Graduate School of Creative Arts and Media (GradCAM), Dublin, Ireland, 25 ${ }^{\text {th }}$ May 2011. Social Science Centre. 2013. "An experiment in free, co-operative higher education." Radical Philosophy, 182 (Nov/Dec): 66-67.

Stallman, Richard. 2010. Free as in Freedom 2.0: Richard Stallman and the Free Software Revolution. Boston: GNU Press.

Stallman, Richard. 2002. Free Software Free Society: Selected essays of Richard Stallman. Boston: GNU Press.

Suber, Peter. 2012. Open Access. Cambridge: MIT Press.

Taylor \& Francis. 2014. Taylor \& Francis Open Access Survey June 2014. Accessed on 18 ${ }^{\text {th }}$ July 2014. http://www.tandfonline.com/page/openaccess/opensurvey/2014

Vieira, Miguel Said and Primavera De Filippi. 2014. "Between Copyleft and Copyfarleft: Advanced reciprocity for the commons." Journal of Peer Production, 4.

Vincent, Nigel and Chris Wickham. 2013. Debating Open Access. London: The British Academy. Access on $18^{\text {th }}$ July 2014.

http://www.britac.ac.uk/openaccess/debatingopenaccess.cfm

Weber, Steven. 2004. The Success of Open Source. Cambridge: Harvard University Press. 
Wendling, Amy E. 2011. Karl Marx on Technology and Alienation. Basingstoke: Palgrave Macmillan.

Wiley, David. 2006. “Open source, openness, and higher education.” Innovate Journal of Online Education, 3(1).

Winn, Joss. 2012. "Open education: from the freedom of things to the freedom of people." In Towards teaching in public: reshaping the modern university, edited by Michael Neary, Howard Stevenson and Les Bell, 133-147. London: Continuum.

Winn, Joss. 2013. "Hacking in the university: contesting the valorisation of academic labour." tripleC : Communication, Capitalism and Critique, 11 (2): 486-503.

Winn, Joss. 2014. "Writing about academic labour.” Workplace: A Journal for Academic Labour, 25: 1-15.

Winn, Joss. 2015. “The co-operative university: Labour, property and pedagogy.” Power and Education, 7 (1). 